THE INSECURE WORLD OF HENRY JAMES'S FICTION 
Also by Ralf Norrman

NATURE AND LANGUAGE: A Semiotic Study of Cucurbits in Literature (with Jon Haarberg)

TECHNIQUES OF AMBIGUITY IN THE

FICTION OF HENRY JAMES 


\section{The Insecure World of Henry James's Fiction}

Intensity and Ambiguity

Ralf Norrman

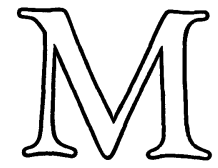




\section{(C) Ralf Norrman 1982}

Softcover reprint of the hardcover 1st edition 1982 978-0-333-32196-6

All rights reserved. No part of this publication may be reproduced or transmitted, in any form or by any means, without permission

First published 1982 by THE MACMILLAN PRESS LTD London and Basingstoke Companies and representatives throughout the world DOI 10.1007/978-1-349-16824-8 
For E-L 
Le style est l'homme même

(Buffon) 


\section{Contents}

Foreword ix

Acknowledgements $\quad$ x

Introduction 1

1. Referential Ambiguity in Pronouns 6

2. End-Linking 66

3. Emphatic Affirmation 84

4. The 'Finding a Formula'-Formula 108

5. Chiastic Inversion, Antithesis and Oxymoron 137

$\begin{array}{ll}\text { Conclusion } & 185\end{array}$

$\begin{array}{ll}\text { Notes and References } & 193\end{array}$

List of Works Cited 207

$\begin{array}{ll}\text { Index } & 211\end{array}$ 


\section{Foreword}

Though published only now, this book was written several years ago. In the time that has passed since then my thinking on James has developed. I have now become firmly convinced that the most important key to an understanding of the psychomorphology of James's thinking is the nature and function of the rhetorical figure of chiasmus, which, in the present study, is dealt with only in the fifth chapter, which is the last. James was what I would like to term a chiasticist: his use of chiastic thinking was habitual and compulsive.

Chapter 5 of the present work is therefore the most important of all chapters, and impatient readers may want to begin with that rather than Chapter 1.

I could of course have rewritten this book, laying more stress on chiasmus, and structuring the text around what is now Chapter 5. However, I decided to let it stand, and to return to James's use of chiasmus in another context.

Meanwhile, I would like to refer any readers who become interested in the nature and function of chiasmus to a book on the subject that I am at present writing, and which I hope will be published in the near future. The preliminary title is Samuel Butler and Chiasmus: A Study of an Ambilateralist Mind. This study will use the works of Samuel Butler (1835-1902) as source of examples but the results will be applicable to Henry James as well, and it is actually astonishing how similar James and Butler were in their ways of thinking. The similarity is accounted for by the fact that both were addicted to one particular pattern of thought - chiasmus.

Oxford

Ralf Norrman

December 1980 


\section{Acknowledgements}

I am grateful to Dr Larzer Ziff of the University of Pennsylvania (formerly of Exeter College, Oxford) for reading drafts of the first two chapters and making a number of helpful comments and suggestions.

I am very grateful for financial assistance from the H.W. Donner Fund.

I wish to thank my wife Eva-Liisa for typing and proofreading and for a number of discussions that brought forth new ideas and helped to put old ones into perspective.

While writing this study I was at Linacre, and for a short time at Queen's. I am grateful to these Oxford colleges, and to the Finnish Academy, for academic hospitality and financial support.

Chapter 1 and an early version of Chapter 2 of this book have appeared as articles in periodicals: 'Referential Ambiguity in Pronouns as a Literary Device in Henry James's The Golden Bowl', Studia Neophilologica, vol. 5 (1979), no. 1, pp. 31-71; 'EndLinking as an Intensity-Creating Device in the Dialogue of Henry James's The Golden Bowl', English Studies, vol. 61 (June 1980), no. 3, pp. 236-51. Some of the material in the present fifth chapter appeared earlier in my essay 'Chiastisk inversion: Ett mönster hos Henry James', in Pegas och Snöbollskrig: Litteraturvetenskapliga studier tillägnade Sven Linnér, Publications of the Research Institute of the Åbo Akademi Foundation, no. 44 (Åbo Akademi, 1979), ss. 209-25. I thank the editors for permission to reprint.

Every effort has been made to trace all copyright holders but if any have been inadvertently overlooked the publishers will be pleased to make the necessary arrangement at the first opportunity. 